\title{
In vitro and in vivo biotinylation of endothelial cell surface proteins in the pursuit of targets for molecular therapies for brain AVMs
} Margaret Simonian $^{1 *}$, Mark P Molloy ${ }^{2}$ and Marcus A Stoodley ${ }^{1}$

${ }^{1}$ Australian School of Advanced Medicine, Macquarie University, North Ryde, NSW, 2109, Australia

${ }^{2}$ Australian Proteomics Analysis Facility (APAF), Department of Chemistry and Biomolecular Sciences, Macquarie University, North Ryde, NSW, 2109, Australia

\begin{abstract}
Identification of membrane proteins that are expressed on the endothelium after radiosurgery is of fundamental importance in developing a new treatment for brain vascular formations. We optimized then employed in vitro and in vivo biotinylation methodology to label membrane proteins in a murine cerebral endothelial cell cultures (bEnd.3) and a rat model of arteriovenous malformation (AVM). Membrane proteins were then captured on streptavidin resin and identified using proteomics analysis.
\end{abstract}

Keywords: Biotinylation; Membrane proteins; Murine cerebral endothelial cells

\section{Introduction}

Arteriovenous malformations (AVMs) consist of a tangle of abnormal arteries and veins linked by one or more fistulae [1,2]. AVMs in the brain can occur in any region, and range in size from small $(<$ $3 \mathrm{~cm})$ to large $(>6 \mathrm{~cm})$. Patients with AVMs present with headaches (migraines), seizures and most commonly haemorrhages. The first haemorrhage is most likely to occur between the ages of 20-40 years $[3,4]$.

Treatment of AVMs depends on their location (eloquent or noneloquent brain) and size $[1,5,6]$. Small AVMs located at the surface of the brain are suitable for direct surgery [2]. Large AVMs are usually wedge-shaped and extend deeper into the brain, these are more difficulty to treat with surgical removal [2].

Embolization involves occluding the blood flow to an AVM using endovascular catheters and can be effective for rare lesions that are less than $1 \mathrm{~cm}$ in diameter and fed by a single artery $[7,8]$. Radiosurgery is a treatment option for lesions $<3 \mathrm{~cm}$ in diameter and located in eloquent areas where surgery can cause neurological deficits [1]. Compared to other treatments, the immediate risk at the time of the radiosurgery is very low. However, vascular occlusion after radiosurgery can take up to 3 years to complete, and patients remain at risk of haemorrhage during this time $[9,10]$.

Approximately one third of AVMs are unsuitable for current treatment methods. Therefore there is a need for a new treatment, that is safer and more effective than current treatment methods for these large and deep lesions

In 2007 a study by Storer et al [11]. demonstrated induction of thromboses in an animal model of AVM treated with radiosurgery by administering lipopolysaccharide (LPS) and tissue factors which is a non-ligand type of vascular targeting. However this approach wasn't successful in the large vessels and there are safety concerns regarding injecting humans with LPS $[11,12]$.

A ligand-based vascular targeting approach has the potential to overcome these problems, but requires a luminal surface molecule that discriminates AVM vessels from normal vessels. We propose that radiosurgery can stimulate the cell surface expression of discriminating proteins. In this study we aim to identify potential protein targets in AVM endothelium after radiosurgery. These protein candidates could then be investigated for ligand-directed treatment to promote rapid thrombosis in AVM vessels. To achieve this goal, a successful labelling of cell surface proteins is crucial.

Here we describe the in vitro and in vivo biotinylation method that we employed to label membrane proteins in the murine endothelial cell culture (bEnd.3) and in an animal model of AVM. Surface biotinylation with biotin derivatives was followed by purification on streptavidin resin. This approach has been shown to be successful in recovering membrane proteins both in in vitro and in vivo studies [13-15]. Membrane proteins were then identified by ESI LS MS/MS analysis.

\section{Materials and Methods}

\section{In vitro biotinylation}

Cell culture: Murine bEnd3 endothelia cells (American Type Culture Collection, VA, USA) were cultured in Dulbecco's Modified Eagle's Medium (DMEM) with $4.5 \mathrm{~g} / \mathrm{L}$ D-glucose (Invitrogen Gibco, CA, USA), $4 \mathrm{mM}$ L-glutamine, and $0.11 \mathrm{~g} / \mathrm{L}$ sodium pyruvate containing $10 \%$ fetal bovine serum (Invitrogen Gibco), HEPES and streptomycine (Invitrogen $\mathrm{Gibco}$ ) in a $5 \% \mathrm{CO}_{2}$ atmosphere at $37^{\circ} \mathrm{C}$. Cells were seeded in $75 \mathrm{CM}^{3}$ tissue culture flasks until $80 \%$ confluent.

Surface biotinylation was performed on the endothelial cell cultures using a modified protocol $[13,14]$

Each $75 \mathrm{~cm}^{2}$ flask containing approximately $1 \times 10^{6}$ cells was washed four times with PBS pH 7.4. Twenty millilitres of PBS containing 67 $\mu \mathrm{M}$ EZ-link (Sulfo-NHS-LC-Biotin) (Pierce, IL, USA) were added to the flasks and incubated for $5 \mathrm{~min}$ at room temperature. The biotinylation reaction was terminated by adding Tris- $\mathrm{Hcl} \mathrm{pH} 7.5$ to a final concentration of $670 \mu \mathrm{M}$. After 5 min incubation the cells

*Corresponding author: Margaret Simonian, Australian School of Advanced Medicine, Macquarie University, Sydney, 2109, Australia, Tel: +61-2-9812 3608; Fax: +61-2-9812 3610; E-mail: Margaret.simonian@mq.edu.au

Received April 17, 2012; Accepted April 28, 2012; Published April 30, 2012

Citation: Simonian M, Molloy MP, Stoodley MA (2012) In Vitro and In Vivo Biotinylation of Endothelial Cell Surface Proteins in the Pursuit of Targets for Vascular Therapies for Brain AVMs. Metabolomics S1:007. doi:10.4172/2153 0769.S1-007

Copyright: (c) 2012 Simonian M, et al. This is an open-access article distributed under the terms of the Creative Commons Attribution License, which permits unrestricted use, distribution, and reproduction in any medium, provided the original author and source are credited. 
Citation: Simonian M, Molloy MP, Stoodley MA (2012) In Vitro and In Vivo Biotinylation of Endothelial Cell Surface Proteins in the Pursuit of Targets for Vascular Therapies for Brain AVMs. Metabolomics S1:007. doi:10.4172/2153-0769.S1-007

were washed four times with PBS and harvested with 2-3 $\mathrm{mL}$ of lysis buffer containing [ $2 \% \mathrm{w} / \mathrm{v}$ NP40, $0.2 \% \mathrm{w} / \mathrm{v}$ SDS and protease inhibitor (Complete, EDTA-free from Roche, Switzerland)] and kept on ice for $30 \mathrm{~min}$.

Capture of biotinylated proteins: Biotinylated proteins were captured on streptavidin sepharose high performance (GE health care, Australia). Five hundred microlitres of streptavidin sepharose were washed three times with buffer A containing (1\% w/v NP40, 0.5\% w/v SDS in PBS) before adding to cell lysates. Samples then were incubated with washed streptavidin sepharose for $2 \mathrm{~h}$ in room temperature. Streptavidin sepharose was pelleted by centrifugation at $1600 \mathrm{~g}$ for $5 \mathrm{~min}$. Unbound proteins were removed by washing 3 times with buffer A, once with buffer $\mathbf{B}(0.1 \% \mathrm{w} / \mathrm{v} \mathrm{NP} 40,0.5 \mathrm{M} \mathrm{NaCl}$ in PBS $)$ and once with digestion buffer $(0.25 \mathrm{mM} \mathrm{AMB})$.

Tryptic digestion of biotinylated proteins and Nano-LC ESI MS/ MS: Streptavidin sepharose was re-suspended in $200 \mu \mathrm{L}$ of digestion buffer. Twenty microlitres of trypsin were then added and incubated overnight at $37^{\circ} \mathrm{C}$. The samples were centrifuged at $14,100 \mathrm{~g}$ for 2 minutes at room temperature. The supernatant was recovered and dried. Samples were then fractionated by strong cation exchange liquid chromatography (SCX) and nanoLC/MS/MS carried out with a Qstar Elite mass spectrometry (AB Sciex, Foster City, CA) as described [16].

\section{In vivo biotinylation of the rat model of AVM}

A rat model of AVM was developed that closely resembles human AVMs [17]. Six weeks after fistula creation, in vivo biotinylation perfusion was carried out on the rat model of AVM as described briefly below.

The rat was narcotized with a subcutaneous injection of combined anaesthesia of (ketamine $100 \mathrm{mg} / \mathrm{mL}$, xylazine $20 \mathrm{mg} / \mathrm{mL}$ and acepromazine $10 \mathrm{mg} / \mathrm{mL}$ ). Using blunt scissors, the skin was cut from the abdomen to the thorax, then dissect to open the peritoneum. The chest was opened through a median sternotomy. The heart was turned around quickly by holding it with forceps at the apex, and an injection needle was inserted into the left ventricle and then to the aorta. A small cut in the right atrium was made with Student Vannas Spring Scissors to allow blood and perfusion solutions to flow out. Using the Gilson Minipuls 3 perfusion pump attached to a tube and needle, the rat was perfused with $1 \mathrm{~L}$ of saline $(\mathrm{NaCl})$ to wash away the blood, then immediately followed with $100 \mathrm{~mL}$ of freshly prepared biotinylation solusion $[1 \mathrm{mg} / \mathrm{mL}$ of EZ-Link, Sulfo-NHS-LC-Biotin in pre warmed PBS at $37^{\circ} \mathrm{C}+10 \%$ Dextran 40 ] by pressing the syringe plug with a flow rate of $30 \mathrm{ml} / \mathrm{min}$ while monitoring the pressure and keeping it constant at $\sim 100 \mathrm{~mm} \mathrm{Hg}$.

After 5 min of perfusing the biotinylation solution, the rat was injected with $100 \mathrm{~mL}$ of $(50 \mathrm{mM}$ Tris-Hcl in PBS $+10 \%$ Dextran 40$)$ with a flow rate of $30 \mathrm{~mL} / \mathrm{min}$ to wash out excessive biotinylation reagent, then was perfused with $200 \mathrm{ml}$ saline at $30 \mathrm{~mL} / \mathrm{min}$ to wash away Dextran. The fistula tissue then was excised and the surrounding fat and muscle tissue was removed. The vascular tissue was placed in a $1 \mathrm{~mL}$ Eppendorf tube and transferred to a $-80^{\circ} \mathrm{C}$ freezer immediately.

\section{Membrane extraction and nano-LC ESI MS/MS}

The tissue sample was pulverized in liquid nitrogen and resuspended in $1 \mathrm{~mL}$ of lysis buffer (20mM HEPES, $150 \mathrm{mM} \mathrm{NaCl}$, $10 \mathrm{mM} \mathrm{NaF}, 1 \mathrm{mM}$ Na-EDTA, $1 \mathrm{mM}$ Na-EGTA, pH 7.5, pH adjusted with $\mathrm{NaOH})+$ protease inhibitor $(4 \mu \mathrm{L}$ per $\mathrm{mL}$ of HEPES buffer, Sigma $\mathrm{P}-2714)$. Each sample was probe sonicated for $3 \times 15 \mathrm{sec}$ in ice using the probe sonicator (Branson sonifier 450, John Morris Scientific) and centrifuged in a pre-cooled rotor at $1,500 \times \mathrm{g}$ for $15 \mathrm{~min}\left(4^{\circ} \mathrm{C}\right)$. The supernatant was collected and pellet was re-lysed with $0.5 \mathrm{~mL}$ of HEPES buffer (same as above steps). The supernatant was collected and pooled with previous supernautant, the final volume of supernatant was $\sim 1.5 \mathrm{~mL}$. Sodium Bicarbonate solution $(0.1 \mathrm{M}, \mathrm{pH} 11)$ was added to pooled supernatant (up to $5 \mathrm{~mL}$ ) and incubated $1 \mathrm{hr}$ at $4^{\circ} \mathrm{C}$ on rocking platform. After incubation, the sample was centrifuged at $120,000 \mathrm{~g}$ for $1 \mathrm{~h}\left(4^{\circ} \mathrm{C}\right)$ using a $\mathrm{S} 80-\mathrm{AT} 3$ rotor.

The pellet was dissolved with $200 \mu \mathrm{L}$ of $100 \mathrm{mM}$ Amonium Bicarbonate containing $10 \mathrm{mM}$ DTT (freshly prepared) in water bath sonication (Transsonic 700/H, John Morris Scientific) for 20 minutes and then incubated for $1 \mathrm{hr}$ at $37^{\circ} \mathrm{C}$ to reduce the sample. To alkalize the sample, $5 \mu \mathrm{L}$ of $1 \mathrm{M}$ idoacetamide stock was added to make final concentration to $20 \mathrm{mM}$ idoacetamide and incubate in dark at room tempreature for $30 \mathrm{~min}$. The sample volume was then brought up to $5 \mathrm{ml}$ with $100 \mathrm{mM}$ Amonium Bicarbonate and centrifuged at 120,000 $\mathrm{x}$ g for $1 \mathrm{hr}\left(4^{\circ} \mathrm{C}\right)$. The pellet was dissolved with $400 \mu \mathrm{L}$ of $100 \mathrm{mM}$ Amonium Bicarbonate in water bath sonication then $600 \mathrm{ul}$ of methanol was added. Membrane proteins were captured on streptavidin beads followed by on-beads proteins digestion with trypsin overnight. Peptides then separated by SCX followed by ESI LC MS/MS as described above.

Figure 1 is a flow diagram of the in vivo rat perfusion and the subsequent sample preparation for proteomics analysis.

\section{Data analysis}

The nanoLC ESI MS/MS data were submitted to Mascot for protein identification using the SwissProt database containing Mus musculus protein entries. Biotinylated lysine and amino terminus were considered as static modifications. Peptide ion scores above 35 were reported giving a probability of correct identification $(\mathrm{P}<0.05)$.

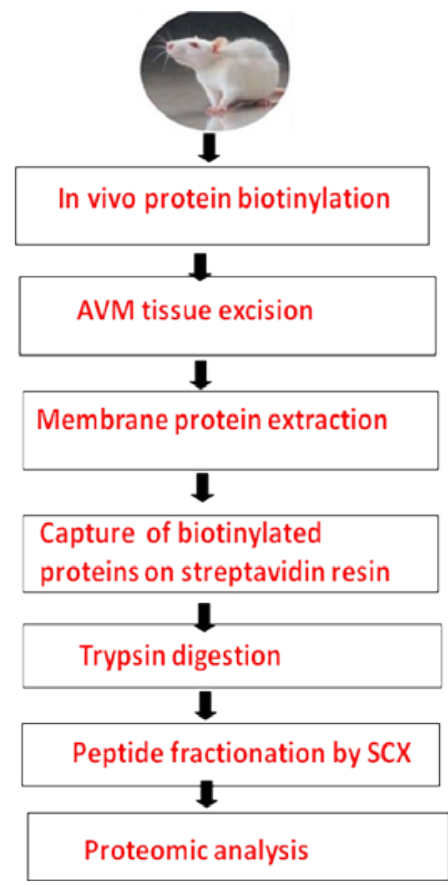

Figure 1: Flow diagram of in vivo perfusion in the rat model of AVM and the subsequent steps. 
Citation: Simonian M, Molloy MP, Stoodley MA (2012) In Vitro and In Vivo Biotinylation of Endothelial Cell Surface Proteins in the Pursuit of Targets for Vascular Therapies for Brain AVMs. Metabolomics S1:007. doi:10.4172/2153-0769.S1-007

Page 3 of 4

\section{Results}

We developed a strategy to derivatize and recover cell surface membrane proteins from cell cultures and a rat AVM animal model and analyses them using mass spectrometry (Figure 1). Recovered, biotinylated peptides from bEnd3 mouse endothelial cells were identified by mass spectrometry (Table 1). Two hundred and thirteen proteins were detected using ProteinPilot. Search of the literature confirmed that 56 of these proteins are annotated as cell membrane proteins. Future work involves determining the expression level changes of membrane proteins in response to irradiation treatment over a time course.

The proteomics data from the AVM rat model detected 135 proteins, 29 were annotated as membrane proteins. Table 2 shows selected membrane proteins.

This data demonstrates the viability of derivatising endothelial cell surface membrane proteins in situ, recovering them and determining their identity using mass spectrometry. We carried further in vivo biotinylation perfusion optimization on another 8 rats, using different biotin concentrations, perfusion rate and time. Harvested AVM tissues

\begin{tabular}{|c|c|c|}
\hline Protein name & $\begin{array}{l}\text { Mascot Protein } \\
\text { Ion }\end{array}$ & $\begin{array}{l}\text { Number of } \\
\text { matched peptides }\end{array}$ \\
\hline $\begin{array}{l}\text { Platelets endothelial cell adhesion } \\
\text { molecule }\end{array}$ & 218 & 4 \\
\hline Lamin-B1 & 219 & 12 \\
\hline Spectrin beta chain, brain-1 & 591 & 21 \\
\hline Tight junction protein ZO-2 & 32 & 1 \\
\hline Sodium/potassium-transporting ATPase & 275 & 4 \\
\hline Ras-related protein Rab-1A & 172 & 4 \\
\hline Transmembrane emp24 domain & 52 & 1 \\
\hline Lamin-B2 & 91 & 3 \\
\hline Tight junction protein ZO-1 & 365 & 8 \\
\hline Glucose-6-phosphate isomerase & 45 & 1 \\
\hline Alpha-internexin & 40 & 3 \\
\hline Cadherin 5 & 179 & 3 \\
\hline Cadherin 13 & 90 & 1 \\
\hline $\begin{array}{l}\text { Endothelial cell-selective adhesion } \\
\text { molecule }\end{array}$ & 152 & 2 \\
\hline Integrin alpha 3 & 149 & 3 \\
\hline Ras-related protein Rab-1B & 138 & 3 \\
\hline Integrin alpha 6 & 86 & 1 \\
\hline Cell surface glycoprotein (Muc18) & 141 & 3 \\
\hline Integrine beta 1 & 123 & 3 \\
\hline $\begin{array}{l}\text { Intercellular adhesion molecule } 2 \\
\text { (ICAM2) }\end{array}$ & 68 & 3 \\
\hline Annexin & 96 & 2 \\
\hline Leukocyte surface antigen CD47 & 97 & 1 \\
\hline Protein disulfide-isomerase & 130 & 3 \\
\hline Ras related $\mathrm{Rab}-10$ & 121 & 2 \\
\hline Catenin alpha-1 & 102 & 3 \\
\hline Ras related Rap-1A & 102 & 2 \\
\hline Calnexin & 88 & 2 \\
\hline $\begin{array}{l}\text { Glyceraldehyde-3-phosphate } \\
\text { dehydrogenase }\end{array}$ & 160 & 4 \\
\hline Voltage-dependent anion-selective prot. & 155 & 3 \\
\hline Dysferlin & 87 & 3 \\
\hline Beta-2-syntrophin & 69 & 1 \\
\hline Ras-interacting protein 1 & 139 & 3 \\
\hline
\end{tabular}

Table 1: Selected bEnd3 membrane proteins identified by mass spectrometry analysis, using mascot search engine, their scores and number of matched peptides.

\begin{tabular}{|l|l|l|}
\hline Protein name & $\begin{array}{l}\text { Mascot } \\
\text { Protein lon }\end{array}$ & $\begin{array}{l}\text { Number of } \\
\text { matched peptides }\end{array}$ \\
\hline Epithelial cell adhesion molecule & 68 & 2 \\
\hline Cadherin 13 & 76 & 1 \\
\hline Platelet glycoprotein & 17 & 1 \\
\hline $\begin{array}{l}\text { V-set domain-containing T-cell activation } \\
\text { inhibitor }\end{array}$ & 48 & 3 \\
\hline Complement C3 & 166 & 6 \\
\hline Sodium/potassium-transporting ATPase & 68 & 1 \\
\hline subunit alpha- & & \\
\hline Serine protease inhibitor A3K & 70 & 2 \\
\hline Angiotensin-converting enzyme & 42 & 2 \\
\hline Lumican & 55 & 1 \\
\hline Complement C4 & 238 & 7 \\
\hline Membrane primary amine oxidase & 131 & 3 \\
\hline Integrin alpha 6 & 96 & 1 \\
\hline Mast cell protease & 84 & 3 \\
\hline Biglycan & 71 & 1 \\
\hline Integrin beta 1 & 87 & 5 \\
\hline Alpha-1-antiproteinase & 156 & 3 \\
\hline Sodium/potassium-transporting ATPase & 44 & 1 \\
\hline Serine protease inhibitor & 137 & 3 \\
\hline Integrin beta 4 & 74 & 1 \\
\hline Lactadherin & 65 & 1 \\
\hline Table & S & \\
\hline
\end{tabular}

Table 2: Selected membrane proteins of AVM rat model identified by mass spectrometry analysis using mascot search engine, their scores and number of matched peptides.

are currently being analysed using proteomics analysis. Future work will involve targeted radiosurgery using AVM rat model followed by the proteomics workflow we described. This will lead to the identification of vascular targets for treatment.

\section{Conclusion}

Cell surface protein biotinylation and mass spectrometry successfully identified membrane proteins from endothelial cell models and vasculature in a rat model of AVM. Our future validation will also include primary endothelial cell cultures from resected AVMs. We will study radiation-induced changes in human AVM endothelial cells using proteomic analysis. Candidate proteins then will be investigated for use in ligand-directed human vascular targeting trials.

\section{Acknowledgment}

We thank Professor Joseph Loo at the University of California Los Angeles, Department of Chemistry and Biochemistry for supporting our project. Thanks to Skipper Research Travel Award.

\section{References}

1. Friedlander RM (2007) Arteriovenous Malformations of the Brain. N Engl J Med 356: $2704-2712$

2. (1999) Arteriovenous malformations of the brain in adults. $\mathrm{N}$ England $\mathrm{J}$ Med 340: 1812-1818.

3. Crawford PM, West CR, Chadwick DW, Shaw MD (1986) Arteriovenous malformations of the brain: natural history in unoperated patients. J Neuro Neurosurg Psychiatry 49: 1-10.

4. Brown RD Jr, Wiebers DO, Torner JC, O'Fallon WM (1996) Frequency of intracranial hemorrhage as a presenting symptom and subtype analysis: a population-based study of intracranial vascular malformations in Olmsted Country, Minnesota. J Neurosurg 85: 29-32.

5. Spetzler RF, Martin NA (1986) A proposed grading system for arteriovenous malformations. J Neurosurg 65: 476-483.

6. Spetzler RF, Hargraves RW, McCormick PW, Zabramski JM, Flom RA, et al (1992) Relationship of perfusion pressure and size to risk of hemorrhage from arteriovenous malformations. J Neurosurg 76: 918-923. 
Citation: Simonian M, Molloy MP, Stoodley MA (2012) In Vitro and In Vivo Biotinylation of Endothelial Cell Surface Proteins in the Pursuit of Targets for Vascular Therapies for Brain AVMs. Metabolomics S1:007. doi:10.4172/2153-0769.S1-007

Page 4 of 4

7. Soderman M, Andersson T, Karlsson B, Wallace M, Edner G (2003) Management of patients with brain arteriovenous malformations. Eur $\mathrm{J}$ Radio 46: $195-205$

8. Weber W, Kis B, Siekmann R, Kuehne D (2007) Endovascular treatment of intracranial arteriovenous malformations with onyx: technical aspect. AJNR Am J Neuroradiol 28: 371-377.

9. Friedman W, Blatt D, Bova F, Buatti J, Mendenhall W, et al. (1998) The risk of hemorrhage after radiosurgery for arteriovenous malformations. J Neurosurg 84: $912-919$

10. Maruyama K, Kawahara N, Shin M (2005) The risk of hemorrhage after radiosurgery for cerebral arteriovenous malformations. N Engl J Med 352: 146153.

11. Storer K, Tu J, Karunanayaka A, Smee R, Short R, et al. (2007) Indcucing thrombosis post radiosurgery. Neurosurgery 61: 604-611.

12. Storer KP, Tu J, Stoodley MA, Smee RI (2010) Expression of endothelial adhesion molecules after radiosurgery in an animal model of arteriovenous malformation. Neurosurgery 67: 976-983.
13. Scheurer SB, Rybak JN, Roesli C, Brunisholz RA, Potthast F, et al. (2005) Identification and relative quantification of membrane proteins by surface biotinylation and two-dimensional peptide mapping. Proteomics 5: 2718-2728.

14. Roesli C, Neri D, Rybak JN (2006) In vivo protein biotinylation and sample preparation for the proteomic identification of organ- and disease-specific antigens accessible from the vasculature. Nat Protocol 1: 192-199.

15. Rybak JN, Ettorre A, Kaissling B, Giavazzi R, Neri D, et al. (2005) In vitro biotin biotinylation for identifiction of organ-specific antigens accessible form the vasculator. Nat Methods 2: 291-298.

16. Song X, Bandow J, Sherman J, Baker JD, Brown PW, et al. (2008) iTRAQ experimental design for plasma biomarker discovery. J Proteome Res 7: 29522958

17. Tu J, Karunanayaka A, Windsor A, Stoodley MA (2010) Comparison of an animal model of arteriovenous malformation with human arteriovenous malformation. J Clin Neurosci 17: 96-102. 